\title{
Academic Master's courses in the field of Nursing: an analysis of course load
}

\author{
Maria Lúcia do Carmo Cruz Robazzi ${ }^{1}$ \\ Alacoque Lorenzini Erdmann² \\ Josicélia Dumêt Fernandes ${ }^{3}$ \\ Rosalina Aparecida Partezani Rodrigues ${ }^{1}$ \\ Valéria Lerch Lunardi ${ }^{4}$
}

Objective: to identify, among the Academic Master's courses, run by Brazilian post-graduate nursing programs, analyzed in the three-yearly evaluation (2007-2009) of the Coordination for the Improvement of Higher Education Personnel (CAPES), the course load stated by the programs for training Master's degree students. Method: a descriptive, quantitative, documental study, with data collected in July 2010, through consulting the above-mentioned Coordination's reports in the item "Programs' Proposals", in the Table of Indicators, available on the Internet. Results: discrepancies were found between the course loads of the 32 Academic Master's courses in the different regions of Brazil, with the smallest having a course load of 315 hours and the largest, 1530 hours. Conclusions: greater discussion is needed about the course load necessary for training the competencies and skills for the profile desired for the students on graduating from the course. The study provides advances in nursing knowledge, as previous investigations on the same issue were not identified. It is hoped that Academic Master's courses in nursing may see themselves in this process and may review their pedagogical decisions in the light of the new models of training/qualification of nursing professionals, centered in science, technology and innovation in the area.

Descriptors: Nursing; Education, Higher; Education, Graduate; Education, Nursing.

\footnotetext{
${ }^{1}$ PhD, Full Professor, Escola de Enfermagem de Ribeirão Preto, Universidade de São Paulo, WHO Collaborating Centre for Nursing Research Development, Brazil.

2 PhD, Full Professor, Departamento de Enfermagem, Universidade Federal de Santa Catarina, Brazil.

${ }^{3} \mathrm{PhD}$, Full Professor, Escola de Enfermagem, Universidade Federal da Bahia, Brazil.

${ }^{4} \mathrm{PhD}$, Associate Professor, Universidade Federal do Rio Grande, Brazil.
}

\section{Corresponding Author:}

Maria Lúcia do Carmo Cruz Robazzi

Universidade de São Paulo. Escola de Enfermagem de Ribeirão Preto

Departamento de Enfermagem Geral e Especializada

Av. dos Bandeirantes, 3900

Bairro: Monte Alegre

CEP: 14040-902, Ribeirão Preto, SP, Brasi

E-mail: avrmlccr@eerp.usp.br 


\section{Cursos de mestrado acadêmico na área de enfermagem: análise da carga horária}

Objetivo: identificar, entre os cursos de Mestrado Acadêmico dos programas de pós-graduação em enfermagem brasileiros, analisados por ocasião da avaliação trienal (2007-2009) da Coordenação de Aperfeiçoamento de Pessoal de Nível Superior, a carga horária informada pelos programas para a formação de mestre. Método: trata-se de estudo descritivo, quantitativo, documental, com dados coletados em julho de 2010, mediante consulta aos relatórios da citada Coordenação, no quesito "Propostas dos Programas", dos Cadernos de Indicadores, disponíveis na web. Resultados: foram encontradas discrepâncias entre as cargas horárias dos 32 cursos de Mestrado Acadêmico das diversas regiões do Brasil, sendo que a menor carga horária foi de 315 horas e a maior de 1.530 horas. Conclusões: há necessidade de maior discussão acerca da carga horária necessária à formação das competências e habilidades para o perfil desejado do egresso. O estudo propicia avanços no conhecimento da enfermagem, pois não foram identificadas investigações pregressas que tratem de tal tema. Espera-se que os cursos de Mestrado Acadêmico de enfermagem percebam-se nesse processo e revejam suas decisões pedagógicas, à luz dos novos modelos de formação/capacitação dos profissionais de enfermagem, centrados na ciência, tecnologia e inovação na área.

Descritores: Enfermagem; Educação Superior; Educação de Pós-Graduação; Educação em Enfermagem.

\section{Cursos de maestría académica en el área de enfermería: análisis de la carga horaria}

Objetivo: identificar, entre los cursos de Maestría Académico de los programas de posgrado brasileños en enfermería, analizados por ocasión de la evaluación trienal (2007-2009) de la Coordinación de Perfeccionamiento de Personal de Nivel Superior, la carga horaria informada por los programas para la formación del maestro. Método: estudio descriptivo, cuantitativo, documental, con datos colectados en julio de 2010, mediante consulta a los informes de la citada Coordinación, en el ítem "Propuestas de los Programas", de los Cuadernos de Indicadores, disponibles en la Web. Resultados: fueron encontradas discrepancias entre las cargas horarias de los 32 cursos de Maestría Académico de las diversas regiones de Brasil, siendo que la menor carga horaria fue de 315 horas y la mayor de 1530 horas. Conclusiones: hay necesidad de mayor discusión acerca de la carga horaria necesaria a la formación de las capacidades y habilidades para el perfil deseado del egreso. El estudio propicia avances en el conocimiento de la enfermería pues no fueron identificadas averiguaciones anteriores que traten de tal tema. Se espera que los cursos de Maestría Académica de enfermería se perciban en ese proceso y revean sus decisiones pedagógicas a la luz de los nuevos modelos de formación/capacitación de los profesionales de enfermería, centrados en la ciencia, tecnología e innovación en el área.

Descriptores: Enfermería; Educación Superior; Educación de Postgrado; Educación en Enfermería.

\section{Introduction}

The stricto sensu post-graduate course* is a system for scientific improvement to follow an undergraduate course. It aims to develop and deepen the training acquired in the ambit of the undergraduate course, leading to the obtaining of the academic degree ${ }^{(1)}$. It is the last stage of formal education; its students proceed from the previous levels of teaching ${ }^{(2)}$; it is directed at the academic training of professionals who are dedicated to specific areas of knowledge, and bestows on them the title of Master or Doctor, assuring them a differentiated professional function.

* A stricto sensu postgraduate degree prepares the student to pursue a career in academia. A lato sensu postgraduate degree is a specialization in a certain area and does not lead to a doctoral degree. Translator's note. 
It aims to train high level human resources for transformative practice in the area of teaching and research, who must have a solid general education. It allows the deepening of knowledge permitting the achievement of a high standard of scientific or technicalprofessional competency, which is impossible to reach within the ambit of an undergraduate course; it offers, in the university, the appropriate setting and resources for undertaking scientific investigation and the creative generosity of the highest forms of the university culture is confirmed ${ }^{(3)}$.

In Brazil, post-graduate studies were instituted in 1961 , by the Law of Directives and Bases of National Education and approved in 1965 by the Federal Council of Education, in Decision 977/65 (Sucupira Decision) (1). In 1968, with Law 5.540 (of Reform of Higher Education), it was institutionalized in two levels (Master's and Doctorate), and from then on there was growth in matriculations in higher education, expansion in institutes and departments, the need for better-qualified teaching bodies and an increase in demand for post-graduate education, reaching an important qualitative standard, distinct from other emerging nations ${ }^{(4-6)}$. Between 1976 and 2009 there was an increase of $370 \%$ in the number of Master's courses and of $685.6 \%$ in the number of Doctorates; between 2004 and 2009, growth was 35.9\% in relation to Master's courses and $34.4 \%$ in relation to Doctorate courses. Their annual growth rates continue high, which shows that the potential for growth remains ${ }^{(2)}$.

In Brazilian nursing, the stricto sensu post-graduate courses started in 1972, with the creation of the Master's course in Rio de Janeiro. A further seven courses at this level were implanted in that decade: in 1981, the first Doctorate course was started in São Paulo. Since then, post-graduate courses in Nursing have expanded the number of programs and courses ${ }^{(4-5)}$.

In other nations in the Americas, this level of teaching occurred prior to in Brazil. In Canada, the recognition of the importance of the nurses and nursing during the Second World War, as well as the expansion of higher education in the post-war period, were decisive factors in the starting of the first Master's courses; one program was created in 1959 at the University of Western Ontario, and another at McGill University two years later(7). In the United States, the first Doctorate program was at Case Western Reserve University in $1979^{(8)}$. In both these countries, the two levels of postgraduate course started prior to in Brazil.

The expansion of Brazilian post-graduate courses and programs has required new knowledge and the need for greater technical-scientific knowledge, with an ethical, social, political and cultural foundation, as requisites and attributes of professional qualification ${ }^{(9)}$.

The evaluation of post-graduate programs is a continual process, fundamental for ensuring the quality of the students' training/qualification. This evaluation is carried out by the Coordination for Improvement of Higher Education Personnel (CAPES), right from the recommendation for the setting up of the course, by means of annual monitoring and three-yearly evaluation of performance. This process is grounded in principles, directives and norms, and the procedures are undertaken by consultants from different Brazilian institutions(5). In the field of nursing, the evaluation occupies an important position, stimulating the programs to achieve goals for increasing the construction of relevant and innovative knowledge of use to society.

In 2010's evaluation, referent to the years 2007 9, there were 41 stricto sensu post-graduate programs in Nursing (PPGEnf). Of these, $92.68 \%$ were Academic Master's (AM) and/or Doctorate (DO) courses, and only three (7.31\%) were Professional Master's (MP) courses $^{(10)}$. In June 2011, Nursing had 53 PPGEnf, accounting for 76 courses: 42 AMs, 24 DOs and 10 MPs, given grades between three and $\operatorname{six}^{(11)}$. In this process of evaluation, a considerable variation in course load between the various nursing AMs was identified. No recommendation about the ideal course load necessary for the courses was found among the criteria established by CAPES concerning the post-graduate courses and programs; one can see, however, some indicators referring to their duration.

It is known that the course load is fundamental to the training of the Master's student, as much in the subjects as in the development of the dissertation; the student on a Master's course must seek a solid education, both in teaching/learning and in research.

The present investigation was undertaken, therefore, with the aim of analyzing the course load of the AM courses in the evaluation of 2007-2009, identifying what had been established for the subjects, for the development of the dissertation, and for other purposes.

It is of key importance to analyze the question of different post-graduate courses' course load, even though these differ, too, in relation to the qualification of the teaching bodies, their research infra-structure and their laboratories, among others. Such an analysis can serve as a foundation for future discussions, not only to reduce the discrepancies detected, given form by the 
diversity presented, but also to bridge gaps extant in the literature on the issue in question.

It is believed that the present study can offer support for the PPGEnfs, in their commitment to the quality of the training of their students. The scarcity of publications should alert one to the importance of the contextualization of the issue, centered on the knowledge gap about this object of study and on its implications in the practice of the training of people with Masters degrees in nursing. The advance in the production of knowledge in nursing depends on the investment in the post-graduate students' learning, which is securely implicated in the course load or in the determination of the time spent in the exercising of learning in the postgraduate programs.

\section{Method}

This is a descriptive, exploratory, quantitative documental study, with data collection undertaken in July 2010. The documents consulted were the Tables of Indicators of the PPGEnfs relating to the AM, available in the item Evaluation, on the CAPES web-page. The consultation of the Program Proposals - filled out by their coordinators - was effected from these Tables, with the information related to the course load for the AM level Nursing courses.

Taking into account that the course load for a Master's course does not change greatly from one year to the next, the course loads for 2009 - the last year of the three-year period - were selected, with 32 courses identified. The Doctorate and/or Professional Master's courses were not investigated, as they were to be the subjects of later studies. Also consulted were the Rules of Procedure/regulations of each of the programs/ universities, obtained from their electronic addresses, seeking the norms in respect of each one.

The data for the course loads and the number of credits for the 32 AM courses were obtained from the Tables of Indicators, both total and separated by subject and others. The information was copied from the Internet into a printed collection instrument, with spaces for inserting the following information: name of the area under evaluation, the program's code and name, the institution which it is run by, the level of the course $(A M)$, requirements for the title (containing the number of credits required for subjects, dissertations and others), the equivalency of the credit in hours and the course load required (the sum of the hours in the subject and others). The course load for the subjects proposed by the courses was calculated, along with that intended for the development of the dissertation and that recorded for the item termed 'others'. The total course load was determined by the sum of these three elements; in the majority of courses, each credit is calculated at 15 hours.

After being copied, this information was typed into an Excel spreadsheet and checked against the printed instrument, more than once, by all the authors, separately, with the aim of ruling out errors. In sequence, the 32 AM courses were codified by sequential numbers $(1,2,3 \ldots)$ to avoid possible constraints; the analysis was made, with the data compared with the literature existing on the subject.

Because it dealt with information in the public domain which did not identify the research's participants and which did not involve human beings, there was no need for approval by the Research Ethics Committee, as called for by Brazilian norms ${ }^{(12)}$.

\section{Results}

Of the 32 AM courses analyzed, 59.37\% are linked with federal universities, $6.25 \%$ with foundations, $31.25 \%$ with state universities and $3.12 \%$ with a private university. Those linked with foundations are located in the North-East Region, where $50 \%$ of AM courses are also linked with federal universities; all courses in the Center-West region are from federal universities; in the Southern Region, only one was linked with a state university; in the South-East Region, where the private university in question is located, $46.66 \%$ are from state universities.

Analyzing the course load made up by the distribution of hours in the subjects, in the dissertation and in 'others', it may be observed that not all present the hours calculated for the development of the dissertations.

The courses are presented below, with the total course loads in ascending order.

Table 1 - Distribution of the Academic Master's courses in Nursing in Brazil, according to total course load and course load calculated for subjects, dissertations and others, $2009(n=32)$

\begin{tabular}{ccccc}
\hline Course & $\begin{array}{c}\text { Course load } \\
\text { Subjects }\end{array}$ & $\begin{array}{c}\text { Course load } \\
\text { Dissertation }\end{array}$ & $\begin{array}{c}\text { Course load } \\
\text { Others }\end{array}$ & Total \\
\hline 32 & 315 & - & - & 315 \\
3 & 270 & 90 & - & 360 \\
4 & 360 & - & - & 360 \\
8 & 360 & - & - & 360
\end{tabular}

(continue...) 
Table 1 - (continuation)

\begin{tabular}{|c|c|c|c|c|}
\hline Course & $\begin{array}{l}\text { Course load } \\
\text { Subjects }\end{array}$ & $\begin{array}{l}\text { Course load } \\
\text { Dissertation }\end{array}$ & $\begin{array}{c}\text { Course load } \\
\text { Others }\end{array}$ & Total \\
\hline 13 & 360 & - & - & 360 \\
\hline 14 & 270 & 90 & - & 360 \\
\hline 15 & 360 & 15 & - & 375 \\
\hline 19 & 375 & - & - & 375 \\
\hline 6 & 408 & - & - & 408 \\
\hline 24 & 450 & - & - & 450 \\
\hline 26 & 300 & 150 & - & 450 \\
\hline 12 & 345 & 120 & - & 465 \\
\hline 7 & 384 & 96 & - & 480 \\
\hline 1 & 360 & 120 & - & 480 \\
\hline 2 & 465 & 150 & - & 615 \\
\hline 18 & 450 & 225 & - & 675 \\
\hline 10 & 600 & 90 & - & 690 \\
\hline 9 & 540 & 180 & - & 720 \\
\hline 20 & 540 & 180 & - & 720 \\
\hline 17 & 525 & 300 & 75 & 900 \\
\hline 22 & 525 & 300 & 75 & 900 \\
\hline 5 & 510 & 450 & - & 960 \\
\hline 16 & 450 & 540 & - & 990 \\
\hline 11 & 510 & 510 & - & 1020 \\
\hline 27 & 300 & 1140 & - & 1440 \\
\hline 28 & 300 & 1140 & - & 1440 \\
\hline 29 & 450 & 990 & - & 1440 \\
\hline 30 & 450 & 990 & - & 1440 \\
\hline 31 & 450 & 990 & - & 1440 \\
\hline 25 & 720 & 720 & - & 1440 \\
\hline 21 & 525 & 975 & - & 1500 \\
\hline 23 & 480 & 1050 & - & 1530 \\
\hline
\end{tabular}

In the North-East Region, the average course load considering all the courses was 402.875; the median was 444 and the standard deviation was 204.5283. In six of the courses analyzed (75\%), each credit corresponded to 15 hours; in one $(12.5 \%)$ to 16 and in another $(12.5 \%)$ to 17 hours. Three (37.5\%) did not calculate, in the total course load, the hours spent in the preparation of the dissertations, which varied from zero to a maximum of 450 hours; as for the subjects, the course load varied from 270 to 510 hours. In the Southern region, it was observed that in relation to the total course load, the average was 570; the median 465 and the standard deviation 250.5494. As for the number of credits, $85.71 \%$ of the courses calculated 15 hours for each credit. In the course load intended for the dissertations, variation was again noted, from zero to 510 hours; as for the subjects, the course load varied from 270 to 600 hours. In the Center-West, an average and median of 877.5 hours was obtained, with a standard deviation of 159.099; the South-East Region, with the most AM courses, had an average of 1067 hours; median 1440 and standard deviation of
462.2569. Only two of the courses, considering the 32 evaluated, calculated 75 hours in the item 'Others'.

In the regions studied, the average course load was 729.34 hours and the median was 806.1 hours. Only the South-East has an average and median over these averages. On the other hand, it is also where the AM course is found with the lowest course load among all the regions of Brazil.

\section{Discussion}

The results point to variations between the course loads of the 32 AM courses in the different regions of Brazil. In the South-East, where the majority of the courses are located, and which has the highest averages, they are centered on state universities, principally in the state of São Paulo. This, however, does not mean that the course load for the integralization of the master's course student must be made equal in all the regions, as one course may be more spread out while another is more intense and compact, considering the economic, social and cultural differences between the different regions of Brazil, which - projected onto the educational work, condition the functioning of the PPGEnfs and the behavior itself of the students, individually considered.

The time for study should be considered and comprise the courses' course load. An investigation carried out at the University of Brasilia, with data collected in 2011, with under-graduate and postgraduate students, identified that the latter study more hours per week, both with printed material and that available online, than undergraduates and prefer to study alone, between six in the evening and midnight ${ }^{(13)}$.

On comparing the present study's results with the literature, there is no evidence of Brazilian studies, and international studies on the subject are few. Most information refers to the years or semesters that courses last, with data not obtained on the ideal course load of an AM.

In the United States, the Master's program in Nursing requires a minimum of one year's full-time study and aims to prepare the students to achieve prominent positions in clinical practice, teaching, research, administration and consultancy. The degrees obtained are Master in Nursing and Master of Science in Nursing ${ }^{(14)}$; in Canada, such programs require a thesis or the development of a large project or work placement. Programs may also include mandatory and elective courses for preparing the students to take up positions in advanced teaching of Nursing, practice, 
administration or the development of policies, and/or provide a foundation for the Doctorate ${ }^{(15)}$.

In Switzerland, at Bern University of Applied Science, the Masters program is a joint effort between Bern, St. Gallen and Zurich Universities of Applied Sciences. This is a three-semester course, totaling 90 credits, directed at full-time students - or for approximately six months for those who opt to do it part-time. It is divided into different modules and, for its completion, requires the presentation of a study (combining knowledge, skills and competencies acquired during the program) which corresponds to 20 credits $^{(16)}$. As the system of credits currently used across Europe is the European Credit Transfer System (ECTS) and an ECTS credit is equivalent to 30 hours of study, this master's program, in particular, has 2700 hours. In England, the Midwifery Studies Course at the University of Southampton, lasts two years full-time; that of Nursing Studies lasts one year full time or up to two years part-time ${ }^{(17)}$.

In Asia, at Singapore's East Asia Institute of Management, the Master in Nursing Education lasts two years part-time and is offered by the Queen Margaret University(18).

In Brazil, determinations in respect of course load for this modality of course were not found in documents belonging to CAPES and/or other bodies promoting postgraduate studies. In general, too, the Brazilian programs require the student's full-time dedication to the course, but a course load - as for the Swiss case - was not found for any Brazilian AM course.

Resolution n. 5 of $10 / 03 / 83$ fixes norms of functioning and accreditation for stricto sensu postgraduate courses; article 10, subsection 4 explains that these courses' Rules of Procedure define the maximum duration of the student's permanency; subsection 5 indicates that this shall be a minimum duration of one year for a Master's and two years for a Doctorate without, however, specifying the course load(19). For the lato sensu modality there is more specific standardization: Resolution CNE/CES n. 1, of 3/04/2001 establishes norms for their functioning and in article 10 explains that the lato sensu post-graduate program must have a minimum duration of 360 hours $^{(20)}$.

In the structure of the National System of Postgraduate Studies, a minimum set of norms defined that the Master's and Doctorate courses had to have a minimum duration of one and two years, respectively, and that in addition to preparing a dissertation or thesis, the candidate should study subjects relating to his or her area of focus and similar areas considered as connected fields ${ }^{(21)}$. As this normatizing set was succinct, in the absence of national regulations, some universities, in exercising their autonomy, established the course load of their AMs in their internal Rules of Procedure, which explains the differences observed in this study.

In Nursing, the purpose of the Master's is to prepare a professional to use new knowledge to provide high quality care and improve professional practice ${ }^{(22)}$. The stricto sensu post-graduate courses in this area have as their mission to create and disseminate knowledge in nursing science through teaching, research and extension courses, maintaining an atmosphere of respect for diversity which is conducive to co-existence and the free debate of ideas, contributing to the development of the population's health care; to train professionals able to learn constantly, prepared to act based on ethical principles and with a view to the full exercising of citizenship and consolidation of the Unified Health System ${ }^{(5)}$.

The achieving of this mission entails considering three relevant aspects as inseparable: course duration, its course load and integralization. It entails, therefore, considering the course load to be compatible with a solid education, contextualized and ethically grounded, as a constitutive element of the profile of qualified graduating students for the title of Master or Doctor.

As the diploma attests to the knowledge received, it must presuppose determined hours of academic work, reflected in the accumulation of knowledge and intellectual maturity, which must be measurable, given the requirements considered necessary. The present study evidenced, however, that some of the courses analyzed have a course load below those required for the lato sensu modality; others do not calculate credits for the development of the dissertation, which is the completion of the $\mathrm{AM}$ and requires time for studying and deepening of the subject area of the research to be undertaken.

Although the production of knowledge in the area of nursing has abundant research covering the phase of description of problems, the search for propositions for intervention in the detected problems is urgent, as well as new approaches and methods for studying new and old problems ${ }^{(23)}$. For this to happen, post-graduate programs' course loads have to be better set up, allowing a more appropriate distribution of hours for study and debate, offering time so that a better founding of the research produced may occur.

In addition to the discordant course load between programs, Brazilian post-graduate programs in nursing 
have other problems needing to be worked on, such as: better deepening of the training acquired by the undergraduate students, identifying which sectors of the job market the students are absorbed into after they graduate, increasing their internationalization to result in visibility abroad, seeking parameters of excellence already reached in more developed countries; increasing the fundraising ability to undertake support projects, development and strengthening of lines of research; and better qualifying the teaching body, among others. Hard work, collective effort, solidarity of stronger programs with those in development, and more resources and greater effort by universities are necessary to face the challenges and minimize such problems ${ }^{(24)}$.

\section{Conclusions}

Variations were observed among course loads of the 32 AMs evaluated by the nursing area of CAPES in the different regions of Brazil, with higher averages in state universities' courses in the South-East Region, principally in the State of São Paulo.

Considering the regions studied, the lowest course load was 315 hours, and the highest was 1,530 hours, which shows a significant variation in the training of professionals for the same title, with the biggest difference found in the South-East.

The training of Masters in nursing with such different course loads is concerning. It does not necessarily mean that the greater the course load, the more qualified the Master's student is. However, the importance of a contextualized, ethically-grounded and politically-committed sound education is reiterated as a constitutive element of a professional profile capable of understanding and contributing to scientific, technological and innovative development for the field of nursing.

The data presented indicates the need for discussion and the search for greater uniformity in the light of the possibilities of validation of subjects attended in other courses with mobility of students between separate programs. Otherwise, the richness of this information may support the understanding of the activities and time invested in the internalization of knowledge versus abstraction and depth of content, depending on the level of training. The students' mastery of advanced knowledge may require differentiated course loads between the same, however, the volume of this content may, based on the results obtained, be the object of further research, depending on the potential of maturity and reading practices, interpretation and discussion exercised by the post-graduate students, according to the programs' teaching modalities, indicating questions and positions in addition to the definition of course load and course duration, irrespective of how much such aspects deserve profound analysis of situations and contexts.

In this respect and after subsequent investigations, it is believed to be important for there to be a recommendation from the CAPES nursing area, so that the course load for AM courses may become less unequal, while still attending to the training of the Master's student with competency and an appropriate profile of qualification for the promotion of autonomy, the development of criticality and of reflective capacity respecting, however, the institutions' autonomy.

The study provides advances in nursing knowledge, as previous investigations of the issue were not identified. It is hoped that the data presented may stimulate the courses to see themselves in this process and to review their pedagogical decisions in the light of new models of training/qualification of nursing professionals, centered on science, technology and innovation in the area, evidencing an ethical, political and technical commitment to better quality of life and health for society and to Brazil's scientific prominence.

\section{References}

1. Almeida A Júnior, Sucupira N, Salgado C, Barreto J Filho, Silva MR, Trigueiro $D$, et al. Parecer CFE no 977/65, aprovado em 3 dez. 1965. Rev Bras Educação. 2005;(30):162-73.

2. Ministério da Educação (BR). Coordenação de Aperfeiçoamento de Pessoal de Nível Superior [Internet]. Plano Nacional de Pós-Graduação - PNPG 2011-2020. Brasília: CAPES; 2010 [acesso 15 dez 2011]. Disponível em: http://www.capes.gov.br/images/stories/ download/Livros-PNPG-Volume-I-Mont.pdf

3. Steiner JE. Qualidade e diversidade institucional na pós-graduação brasileira. Estudos Avançados. 2005;19(54):341-65.

4. Padilha MICS, Borenstein MS, Maia AR, Guedes JAD, Lessmann JC, Machado CA. Uma história de sucesso: 30 anos da pós-graduação em enfermagem da UFSC. Texto Contexto Enferm. 2006;15(Esp):20-30.

5. Erdmann AL, Fernandes JD, Teixeira GA. Panorama da Educação em Enfermagem no Brasil: graduação e pósgraduação. Enfermagem em Foco 2011:2(Supll);89-93. 6. Centro de Gestão e Estudos Estratégicos (CGEE) (BR). 
Doutores 2010: estudos da demografia da base técnicocientífica brasileira [Internet]. Brasília, DF: Centro de Gestão e Estudos Estratégicos; 2010 [acesso 20 set 2010]. Disponível em: http://www.inovacao.unicamp. br/report/inte-doutoresdemografiaII100628.pdf

7. Wood M, Giovannetti P, Ross-Kerr JC. The Canadian PHD in nursing: a discussion paper [Internet]. Ottawa, ON: Canadian Association of Schools of Nursing; 2004 [acesso 15 dez 2011]. Disponível em: http:// www.casn.ca/vm/newvisual/attachments/856/Media/ THECANADIANPHDINNURSING.pd

8. American Association of Colleges of Nursing. Position Statement on the Practice Doctorate in Nursing October 2004 [Internet]. Washington: AACN [acesso 3 jan 2012]. Disponível em: http://www.aacn.nche.edu/publications/ position/DNPpositionstatement.pdf

9. Teixeira E, Vale EG, Fernandes JD, De Sordi MRL. Trajetória e tendências dos cursos de enfermagem no Brasil. Rev Bras Enferm. 2006;59(4):479-87.

10. CAPES Coordenação de Aperfeiçoamento de Pessoal de Nível Superior. Relação de cursos recomendados e reconhecidos. Grande área: Ciências da Saúde. Área: Enfermagem [Internet]. Brasília: Ministério da Educação. [acesso 17 out 2011]. Disponível em: http:// conteudoweb.capes.gov.br/conteudoweb/ProjetoRela caoCursosServlet?acao $=$ pesquisarIes\&codigoArea $=40$ 400000\&descricaoArea $=$ CI $\%$ CANCIAS $+D A+S A \% D A D$ $\mathrm{E}+$ \&descricaoAreaConhecimento $=$ ENFERMAGEM\&des cricaoAreaAvaliacao $=$ ENFERMAGEM

11. CAPES Coordenação de Aperfeiçoamento de Pessoal de Nível Superior (BR). Resultados Avaliação Trienal [Internet]. Brasília: Ministério da Educação; 2010 [acesso 17 out 2010]. Disponível em: http://trienal. capes.gov.br/wp-content/uploads/2010/09/Resultadospor-Área.pdf

12. Conselho Nacional de Saúde (BR). Comissão Nacional de Ética em Pesquisa. Perguntas e respostas: pesquisas que envolvem somente dados de domínio publico devem ser analisados pelo sistema CEP/CONEP? [acesso 10 mar 2012]. Disponível em: http://conselho.saude.gov. br/web_comissoes/conep/aquivos/documentos/08_set_ perguntas_respostas.pdf

13. Peixoto HM, Peixoto MM, Alves ED. Estratégias de aprendizagem utilizadas por graduandos e pósgraduandos em disciplinas semipresenciais da área de saúde. Rev. Latino-Am. Enfermagem. [Internet]. maio-jun 2012 [acesso 1 out 2012 ];20(3):[8 telas]. Disponível em: http://www.scielo.br/pdf/rlae/v20n3/ pt_a17v20n3.pdf

14. USZ Klebelsberg Library [Internet]. Nursing education and practice in the United state. [acesso 15 dez 2011]. Disponível em: http://www.bibl.u-szeged. hu/afik/nursingw.html

15. Canadian Association of Schools of Nursing. Position Statement on Master's Level of Nursing [Internet]. Ottawa: CASN; 2011 [acesso 15 dez 2011]. Disponível em: http://casn.ca/vm/newvisual/attachments/856/ Media/MasterslevelofNursing.pdf

16. Bern University of Applied Sciences [Internet]. Master of Science in Nursing. [acesso 15 dez 2011]. Disponível em: http://www.gesundheit.bfh.ch/en/ master/nursing/tabs/costs.html

17. Hotcourses.com.br. Para estudantes brasileiros que querem estudar no exterior [Internet]. Nursing Studies MSc: University of Southampton, Reino Unido. [acesso 18 ago 2012]. Disponível em: http://www.southampton. ac.uk/healthsciences/postgraduate/taught_courses/ msc_nursing_studies.page

18. Masterstudies.com. Your Gateway to Higher Education since 2002. Masters degree in Master in Nursing Education - Master in Master in Nursing Education. [acesso 3 jan 2012]. Disponível em http://www.masterstudies.com/MSc-Masters-Degree/ Biological-and-Life-Sciences/Health-Sciences/Masterin-Nursing-Education/

19. CAPES Coordenação de Aperfeiçoamento de Pessoal de Nível Superior (BR). Resolução n. 5, de 10/03/83. Fixa normas de funcionamento e credenciamento dos cursos de pós-graduação stricto sensu [Internet]. [acesso 20 ago 2011]. Disponível em: http://www. capes.gov.br/images/stories/download/legislacao/ Resolucao_CFE_05_1983.pdf

20. CAPES Coordenação de Aperfeiçoamento de Pessoal de Nível Superior (BR). [Internet]. Brasília: Ministério da Educação. Pós-graduação perde seu idealizador [acesso 20 ago 2011]. Disponível em: http://www.capes.gov.br/ servicos/sala-de-imprensa/36-noticias/1880

21. CAPES Coordenação de Aperfeiçoamento de Pessoal de Nível Superior (BR). [Internet]. Brasília: Ministério da Educação. Plano Nacional de Pós-Graduação - PNPG 2005/2010 [acesso 20 ago 2011]. Disponível em: http:// www.capes.gov.br/sobre-a-capes/plano-nacional-depos-graduacao/pnpgs-anteriores

22. American Association of Colleges of Nursing. The essentials of master education for advanced practice nursing [Internet]. Washington: AACN [acesso 3 jan 2012]. Disponível em: http://www.aacn.nche.edu/ education-resources/MasEssentials96.pdf

23. Zanetti ML. Porque é difícil publicar em periódicos de alto impacto?. Rev. Latino-Am. Enfermagem 
[periódico na Internet]. 2012 Aug [acesso 5 out 2012]; 20(4):633-4. Disponível em: http://www. scielo.br/scielo.php?script $=$ sci_arttext\&pid $=$ S0104$11692012000400001 \&$ Ing $=$ en. $\quad$ http://dx.doi. org/10.1590/S0104-11692012000400001

24. Robazzi MLCC. Stricto sensu Nursing graduate programs performance and the pursuit of excellence. Rev. Latino-Am. Enfermagem. [periódico na Internet]. 2010 Out [acesso 18 ago 2012]; 18(5): 839-40. Disponível em: http://www.scielo. br/scielo.php?script $=$ sci_arttext\&pid $=$ S0104$11692010000500001 \&$ lng $=$ pt. http://dx.doi. org/10.1590/S0104-11692010000500001. 